\title{
Use of Online Learning Resources in the Development of Learning Environments at the Intersection of Formal and Informal Learning: The Student as Autonomous Designer
}

Maja LebeničniK ${ }^{\star 1}$, IAN PitT ${ }^{2}$, AND Andreja Istenič StarČIČ ${ }^{3}$

$\approx$ Learning resources that are used in the education of university students are often available online. The nature of new technologies causes an interweaving of formal and informal learning, with the result that a more active role is expected from students with regard to the use of ICT for their learning. The variety of online learning resources (learning content and learning tools) facilitates informed use and enables students to create the learning environment that is most appropriate for their personal learning needs and preferences. In contemporary society, the creation of an inclusive learning environment supported by ICT is pervasive. The model of Universal Design for Learning is becoming increasingly significant in responding to the need for inclusive learning environments. In this article, we categorize different online learning activities into the principles of Universal Design for Learning. This study examines ICT use among university students $(\mathrm{N}=138)$, comparing student teachers with students in other study programs. The findings indicate that among all students, activities with lower demands for engagement are most common. Some differences were observed between student teachers and students from other programs. Student teachers were more likely than their peers to perform certain activities aimed at meeting diverse learner needs, but the percentage of students performing more advanced activities was higher for students in other study programs than for student teachers. The categorization of activities revealed that student teachers are less likely to undertake activities that involve interaction with others. Among the sample of student teachers, we found that personal innovativeness is correlated with diversity of activities in only one category. The results show that student teachers should be encouraged to perform more advanced activities, especially activities involving interaction with others, collaborative learning and use of ICT to plan and organize their own learning processes.

Keywords: higher education, e-learning activities, online learning resources, teacher education, Universal Design for Learning

$1{ }^{\star}$ Corresponding Author. Faculty of Education, University of Primorska, Slovenia; maja. lebenicnik@pef.upr.si

2 Department of Computer Science, University College Cork, Ireland

3 Faculty of Education, University of Primorska, Slovenia and Faculty of Civil and Geodetical Engineering, University of Ljubljana, Slovenia 


\section{Uporaba na spletu dostopnih učnih virov pri razvijanju učnih okolij na križišču formalnega in neformalnega učenja: študent kot avtonomni oblikovalec}

Maja LebeničniK*, Ian Pitt in Andreja Istenič Starčič

$\propto$ Učni viri, ki jih uporabljajo študentje, so pogosto dostopni na spletu. Narava novih tehnologij povzroča prepletanje formalnega in neformalnega učenja, pri čemer se od študentov pričakuje aktivnejšo vlogo pri uporabi informacijsko-komunikacijskih tehnologij (IKT) za učenje. Raznolikost spletnih učnih virov (spletnih vsebin in orodij) olajša zavedno uporabo in študentom omogoča oblikovanje učnega okolja, ki najbolj ustreza njihovim učnim potrebam in preferencam. V sodobni družbi se inkluzivno učno okolje pogosto ustvarja z uporabo IKT. Model 'univerzalnega oblikovanja za učenje' (Universal Design for Learning - UDL) postaja vse pomembnejši pri odgovoru na potrebe inkluzivnega učnega okolja. V članku smo kategorizirali spletne učne aktivnosti po načelih modela UDL. Raziskava preučuje uporabo IKT med univerzitetnimi študenti $(\mathrm{N}=138)$ in primerja študente pedagoških smeri s študenti drugih programov. Izsledki so pokazali, da so pri obeh skupinah študentov bolj izvajane aktivnosti, ki zahtevajo manj udejstvovanja. Pokazale so se nekatere razlike med študenti pedagoških in drugih smeri. Študentje pedagoških smeri so $\mathrm{v}$ večji meri kot njihovi vrstniki izvajali aktivnosti za vzpostavljanje inkluzivnega učnega okolja. Odstotek študentov, ki so izvajali zahtevnejše IKT-učne aktivnosti, pa je bil višji med študenti nepedagoških smeri. Kategorizacija aktivnosti je pokazala, da študentje pedagoških smeri manj verjetno kot njihovi vrstniki izvajajo aktivnosti, ki zahtevajo interakcijo $\mathrm{z}$ drugimi. Na vzorcu študentov pedagoških smeri smo odkrili, da osebna inovativnost korelira $\mathrm{z}$ raznolikostjo izvajanih aktivnosti pri eni izmed kategorij. Rezultati kažejo, da bi bilo treba študente pedagoških ved bolj spodbujati k izvajanju zahtevnejših IKT-učnih aktivnostih, predvsem aktivnosti, ki vključujejo interakcijo, sodelovalno učenje ter uporabo IKT za načrtovanje in organiziranje lastnega učnega procesa.

Ključne besede: visokošolsko izobraževanje, aktivnosti e-učenja, spletni učni viri, izobraževanje učiteljev, model 'univerzalno oblikovanje za učenje’ 


\section{Introduction}

Information and communication technology (ICT) development is bringing new patterns of behaviour to many aspects of society, including university settings. Institutions in higher education mostly use limited forms of ICT-supported learning, such as course management systems, virtual learning environments and web-based applications to deliver curriculum and student support (Jelfs \& Richardson, 2013; McLoughlin \& Lee, 2010). Some universities provide distance education, and lately some provide video lectures and online courses. Because of the speed and the nature of technological changes, novel ICT technologies are harder to implement in formal learning environments. The official university curriculum is now more oriented towards empowering students' competencies for preparing their own learning environment as well as self-regulation abilities, the setting of learning goals and the acceptance of responsibility. Since universities do not provide fixed e-learning environments, students are expected to be more active and resourceful with regard to the use of ICT to support learning. In this connection, the literature reveals some personal factors in connection with personal innovativeness (Agarwal \& Prasad, 1998). University students report that the use of ICT is expected of them at university, even though the formal training for such skills is often missing (Conole, de Laat, Dillon, \& Darby, 2008). ICT skills, beneficial for learning purposes, are therefore often developed in informal ways, such as with ICT use for leisure, self-initiated exploratory behaviour and information from peers, family or media (Straub, 2009).

\section{Informal online learning in the university context}

Due to the benefits of digitalized online information, online learning resources represent one of the most common sources for learning among university students. Students nowadays are not limited to electronic resources produced and delivered by their universities and can access an abundance of online learning resources themselves. This increases the importance of informal learning environment and personal preferences in the modern university context. According to the International Standard Classification of Education (ISCED) (in UNESCO, 2011, p. 9), informal learning is deliberate, which distinguishes it from random learning, but not institutionalized, which distinguishes it from formal learning. Informal learning activities can be self-, family- or socially-directed. The criterion of institutionalization for formal learning activities is strict, but some scholars introduce a less rigorous distinction on 
the formal-informal continuum. Indicators in these cases are related to the structure and process of learning, especially in terms of how much control the student has in the selection of learning content and evaluation of knowledge (Lai, Khaddage, \& Knezek, 2013). New online and mobile technologies support new forms of formal, informal and random learning. The boundaries between formal and informal learning are blurring (Mills, Knezek, \& Khaddage, 2014; Straub, 2009). Informal online learning, as covered in this chapter, refers to the use of online learning resources: online learning content (e.g. video lectures, tutorials, online courses, e-books etc.) and (online) learning tools (e.g. mind-mapping, quizzes etc.) that students were not introduced to in the process of formal learning. Such informal learning is a consequence of new information seeking and sharing behaviours in Web 2.0 environments (Mills et al., 2014). Anderson (2008) defines forms of interaction occurring between the main players during online learning. The learner can interact directly with online content (independent learning) or follow the online content that the teacher prepares for him (structured online learning resources). With communication and collaboration technologies, an interaction between teacher and learners (community of inquiry) or between students themselves (collaborative learning) is possible. "Content-content interaction" is interaction between learning content and automated information sources. It results in the updating of the content or the monitoring of different groups of users. Technology is becoming increasingly pervasive in university learning environments, which is why students and professors must develop their ICT competency and ICT literacy in order to be able to manage the various online learning resources that are constantly emerging.

\section{Use of online learning resources for meeting personal learning needs}

Online learning content is accessible through different kinds (text, images, sounds, and artefacts) (Moore \& Kearsley, 2012) and forms of media (adaptive, interactive, narrative, productive) (Laurillard, 2002). The informed user can employ various online learning resources to create a learning environment that suits his personal learning needs (e.g. learning styles, individual accessibility needs, motivation, etc.). In addition to the knowledge of different types of ICT, it is important to understand someone's personal learning needs. The survey by Conole et al. (2008) revealed that university students are, in fact, selecting appropriate technologies to suit their personal learning needs. Furthermore, the type of student who benefits the most from using ICT for 
learning is the one whose usage of ICT is central to how the learning is organized and orientated. Such awareness in student teachers may even lead towards greater competency for creating inclusive learning environments in the future. Teachers need knowledge and competence regarding technological possibilities in order to encourage learners' choices and decisions about the most appropriate technology. To satisfy the needs and accessibility requirements of diverse students, teachers should be familiar with different kinds of existing ICT: mainstream ICT, as well as specialized and assistive technology.

Because the individual plays an increasingly active role, personal factors play an important part in adopting ICT for learning. One such factor, personal innovativeness (PI), is defined as the "willingness of an individual to try out any new information technology" (Agarwal \& Prasad, 1998). Personal innovativeness is not strictly defined as a stable personal trait but acts as a moderator between personal traits and behaviour. People who have a higher PI are more likely to adopt IT earlier because they tend to form more positive perceptions of innovation and the consequences of its use than others working with the same information. People with higher PI are also less dependent on the opinions of others, and often act as opinion leaders in their environment (Agarwal \& Prasad, 1998).

\section{ICT-supported learning activities from the perspective of Universal Design}

Several groups of ICT/online learning activities, commonly performed by university students, were identified by different scholars: use of online resources, use of university e-environments, use of communication and collaboration ICT for learning, and use of tools for production.

Students use online resources to look for information, explore learning topics or for general inquiry (Conole et al., 2008; Sedek, Mahmud, Jalil, \& Daud, 2012; Thompson, 2013). This may include watching educational videos and video lectures, reading e-books, online articles, slides, online text and documents, and blogs, and listening to podcasts, etc. Levy (2008) labelled listening, watching and reading of online learning content as passive learning activities. Another relevant ICT-activity is the use of university e-learning environments (Conole et al., 2008). Learning management system software used by universities (e.g. Moodle, Blackboard etc.), "provides learners with a comprehensive environment for communicating with instructors, submitting assignments, reviewing course objectives, downloading course material, participating in course discussions and viewing course progress" (Thoms \& Eryilmaz, 2014, p. 113). In 
Slovenia, the established expression for LMS is "e-classroom". Furthermore, students use communication and collaboration technologies for learning. They support user interaction, content sharing, communication, collaboration and creation of online social networks. Examples of such tools include wiki software, social networking sites, collaborative document management systems, online forums, chat applications, video/audio conference, etc. (Arkilic, Peker, \& Uyar, 2013; Bennett, Bishop, Dalgarno, Waycott, \& Kennedy, 2012; Calvo, Arbiol, \& Iglesias, 2014; Dabbagh \& Kitsantas, 2012)

Students use technology such as creation/productivity tools to prepare study assignments and multimedia products (Conole et al., 2008; Sedek et al., 2012; Thompson, 2013).

Many online learning activities exist, but are less frequently performed by university students and therefore not covered by the abovementioned studies, such as playing educational games, using virtual environments for learning, participating in online courses, using ICT for self-assessment, using ICT for planning the learning process.

Many previous researchers qualitatively or quantitatively explored the use of e-learning activities among university students (Conole et al., 20o8; Jelfs \& Richardson, 2013; Sedek et al., 2012; Thompson, 2013). Recently, attempts have been made to place e-learning activities within the framework of Universal Design (Izzo, 2012; Ravanelli \& Serina, 2014). Universal Design (UD) "is the design and composition of an environment so that it can be accessed, understood and used to the greatest extent possible by all people regardless of their age, size, ability or disability" (Centre for Excellence in Universal Design, 2012). It is an approach that considers the diverse needs and abilities of users during the design process, resulting in benefits for all users, not just users with disabilities. It can be applied not only to physical objects such as the built environment and products, but also services and ICT design. UD introduces seven design principles that are, if adjusted, useful in specific fields such as web accessibility (Web Accessibility Initiative, 2005) or in establishing inclusive learning environments. There are several Universal Design educational models that focus on reducing barriers in learning environments, increasing access to the curriculum and providing instruction for diverse learners (Rao, Ok, \& Bryant, 2014). One of most established models is Universal Design for Learning, which is a framework for guiding educational practice and a set of principles for curriculum development that give all individuals equal opportunities to learn (National Center on Universal Design for Learning, 2014). Three basic principles of UDL are 1) multiple means of representation, 2) multiple means of action and expression, and 3 ) multiple means of engagement. Principle 1 takes into account 
that learners have different ways of perceiving and comprehending information, depending on their sensory or learning (dis)ability, language or cultural differences or learning styles. Principle 2 acknowledges differences in navigation in learning environments (e.g. because of physical disability) and differences in expressing knowledge (e.g. written/spoken form). Principle 3 reveals affect as a source of differences between learners (e.g. different preferences for routine, collaborative work, internal/external motivators, etc.) Following UDL principles and guidelines, teachers are encouraged to provide multiple activities in order to meet the diverse needs of students, along with the use of appropriate ICT.

\section{Purpose, objectives, and hypothesis}

The purpose of the survey was to research the use of online learning resources for learning among Slovenian university students at the intersection of formal and informal learning environments. As pointed out before, knowledge and competencies for ICT use can be acquired through informal activities and can be beneficial for establishing learning environments that are synchronized with an individual's personal learning needs. This should be especially true of student teachers, who will be expected to be able to establish learning environments to meet diverse students' needs. That is why research into habits in this field is crucial, because it may reveal whether important differences exist between student teachers and their peers, and whether the formal curriculum of student teachers should put more emphasis on developing ICT competency. An additional contribution of our study is an attempt to categorize e-learning activities in the framework of Universal Design for Learning.

The research objectives of the survey were:

1. To research the incidence of certain ICT-supported learning activities among Slovenian university students;

2. To compare the incidence of certain ICT-supported learning activities among student teachers with students in other study programs;

3. To compare the diversity of ICT-supported learning activities among student teachers with students in other study programs;

4. To assess the correlation between personal innovativeness and the performance of diverse ICT-supported learning activities among student teachers.

The research hypotheses were:

- Hypothesis 1: There are differences in the performance of specific 
ICT-supported learning activities among student teachers and students in other study programs.

- Hypothesis 2: There are differences in the diversity of activities between student teachers and students in other study programs.

- Hypothesis 3: Personal innovativeness is positively correlated with diversity of use of ICT-supported learning activities among student teachers.

\section{Method}

\section{Participants and data collection}

The survey was conducted on 138 Slovenian university students $(14.5 \%$ male and $85.5 \%$-female participants); $36.2 \%$ of the entire sample were students from education study programs (student teachers), $46.4 \%$ students from other social sciences and humanities study programs and $17.4 \%$ students from science and engineering programs. Ten students (7.2\%) reported having special educational needs.

Participants answered a questionnaire in either online or in paperpencil form. The questionnaire included demographic questions and questions regarding the performance of 25 different e-learning activities and 13 ICT-activities to support diverse learners needs (e.g. use of assistive technology). For each item, participants could reply with a "yes" or "no" answer. Items were later categorized following UDL principles and Anderson's model. The number of activities performed in each category is a measure of the diversity of activities performed.

ICT-activities listed in the questionnaire were identified in the literature review. We included more common online learning activities as well as less frequently performed activities. Furthermore, activities described as learning activities in the UDL literature (e.g. use of dictionaries, ICT for organizing learning process) are included in the questionnaire.

Because we were particularly interested in student teachers, we also asked them to complete the Personal Innovativeness Scale by Kim, Mirusmonov and Lee (2010).

\section{Data analysis}

The analysis was conducted using SPSS. The following tests were used to test the hypotheses: Chi Square test (with continuity correction) for H1, MannWhitney $\mathrm{U}$ test for $\mathrm{H}_{2}$, and Spearman correlation for $\mathrm{H}_{3}$. 


\section{Results and discussion}

The incidence of the specific activities and the diversity of activities performed is examined. For a group of students in education programs, the correlation between personal innovativeness and the performance of ICT-supported learning activities is presented.

\section{The incidence of specific ICT-supported learning activities}

Activities included in the questionnaire can be divided into two subtypes. The first type (items 1-25) are more general e-learning activities, identified in the literature review. More than $90 \%$ of students search for online articles, study literature and use e-dictionaries or translation applications. The majority of activities, performed by more than $60 \%$ of students, are in fact activities identified by Conole et al. (2008): use of ICT for information seeking and handling, assignment preparation, communication and integrated learning. Activities requiring more active engagement from students (e.g. participation in online courses, playing educational games, using e-tools for managing the learning process, producing multimodal outcomes, etc.) represented less than $45 \%$. Activities involving communication and collaboration with others represented between 60 and $80 \%$.

ICT activities that can be used to meet the accessibility and learning needs and preferences of diverse learners are placed under items 26-38. As expected, the incidence of such activities is much lower. Even though one may think that such activities are beneficial only to students with special needs, mainstream students with different learning styles may also benefit from their use. With the exception of changing the settings of mainstream software and hardware, all other activities have a frequency of around $20 \%$ or less.

Table 1. Frequencies of different groups of students stating "yes" on the question of performing specific ICT activity.

\begin{tabular}{|c|c|c|c|c|c|c|}
\hline Item & & $\begin{array}{l}\text { All } \\
(\%)\end{array}$ & $\begin{array}{c}\text { Education } \\
\text { programs } \\
\text { (\%) }\end{array}$ & $\begin{array}{l}\text { Other } \\
\text { programs } \\
\text { (\%) }\end{array}$ & $\begin{array}{c}\text { Chi-square } \\
\text { test }^{\mathrm{a}} \\
(\mathrm{df}=1)\end{array}$ & Sign. \\
\hline & E-learning activity & & & & & \\
\hline 1 & Using e-classroom for learning & 84.8 & 82 & 86.4 & 0.19 & 0.66 \\
\hline 2 & Reading electronic books & 60.1 & 48.0 & 67.0 & 4.06 & $0.04^{*}$ \\
\hline 3 & Searching articles in scientific databases & 94.9 & 96 & 94.3 & 0.00 & 0.98 \\
\hline 4 & $\begin{array}{l}\text { Searching literature in electronic library } \\
\text { catalogues }\end{array}$ & 94.2 & 90 & 96.6 & 1.47 & 0.23 \\
\hline
\end{tabular}




\begin{tabular}{|c|c|c|c|c|c|c|}
\hline 5 & Reading online encyclopaedias & 73.2 & 64.0 & 78.4 & 2.68 & 0.10 \\
\hline 6 & $\begin{array}{l}\text { Reading blogs, concerning my study } \\
\text { field }\end{array}$ & 70.3 & 62 & 75 & 1.99 & 0.16 \\
\hline 7 & Participating in online courses & 12.3 & 4 & 17 & 3.89 & $0.05^{*}$ \\
\hline 8 & Listening to educational podcasts & 43.5 & 32 & 50 & 3.50 & 0.06 \\
\hline 9 & Watching educational videos & 84.1 & 86 & 83 & 0.05 & 0.82 \\
\hline 10 & $\begin{array}{l}\text { Using other (foreign) universities' elec- } \\
\text { tronic educational materials and videos }\end{array}$ & 59.4 & 40 & 70.5 & 11.03 & $0.00^{* *}$ \\
\hline 11 & Playing educational games & 39.1 & 46 & 35.2 & 1.13 & 0.29 \\
\hline 12 & $\begin{array}{l}\text { E-tools for self-assessment (e.g. quizzes, } \\
\text { personality questionnaires etc.) }\end{array}$ & 60.1 & 72 & 53.4 & 3.85 & $0.05^{*}$ \\
\hline 13 & Using educational mobile applications & 36.2 & 38 & 35.2 & 0.02 & 0.89 \\
\hline 14 & $\begin{array}{l}\text { Using virtual environments for learning } \\
\text { (e.g. Second Life, etc.) }\end{array}$ & 11.6 & 14 & 10.2 & 0.15 & 0.70 \\
\hline 15 & $\begin{array}{l}\text { Composing multimodal text and other } \\
\text { outcomes (combining text, audio or } \\
\text { video) }\end{array}$ & 43.5 & 64 & 31.8 & 12.16 & $0.00^{* *}$ \\
\hline 16 & Using electronic citation tools & 52.2 & 58 & 48.9 & 0.73 & 0.39 \\
\hline 17 & $\begin{array}{l}\text { Using social networks for learning: } \\
\text { following shared information about my } \\
\text { study field }\end{array}$ & 82.6 & 76 & 87.4 & 2.18 & 0.14 \\
\hline 18 & $\begin{array}{l}\text { Using social networks for learning: learn- } \\
\text { ing about events, connected to my study } \\
\text { field (e.g. seminars, training, etc.) }\end{array}$ & 89.1 & 90 & 88.6 & 0.00 & 1.00 \\
\hline 19 & $\begin{array}{l}\text { Using social networks for learning: shar- } \\
\text { ing information about my study field }\end{array}$ & 69.6 & 58 & 76.1 & 4.13 & $0.04^{*}$ \\
\hline 20 & $\begin{array}{l}\text { Sharing my files with others (using } \\
\text { Dropbox, Google Drive, etc.) for pur- } \\
\text { poses of study }\end{array}$ & 81.2 & 74 & 85.2 & 1.94 & 0.16 \\
\hline 21 & $\begin{array}{l}\text { Producing shared documents with oth- } \\
\text { ers (using Dropbox, Google Drive, etc.) } \\
\text { for purposes of study }\end{array}$ & 66.7 & 54 & 73.9 & 4.80 & $0.03^{*}$ \\
\hline 22 & $\begin{array}{l}\text { Using electronic dictionaries for search- } \\
\text { ing Slovenian words. }\end{array}$ & 91.3 & 94 & 89.8 & 0.28 & 0.59 \\
\hline 23 & $\begin{array}{l}\text { Using electronic dictionaries or transla- } \\
\text { tion applications for searching words in } \\
\text { foreign languages. }\end{array}$ & 96.4 & 94 & 97.7 & 0.42 & 0.51 \\
\hline 24 & $\begin{array}{l}\text { Using e-tools for making and organizing } \\
\text { notes (e.g. OneNote, etc.) }\end{array}$ & 22.5 & 18 & 25 & 0.54 & 0.46 \\
\hline 25 & $\begin{array}{l}\text { Using e-tools for planning the learning } \\
\text { process (e.g. Google Calendar, etc.) }\end{array}$ & 30.4 & 24 & 34.1 & 1.094 & 0.30 \\
\hline & \multicolumn{6}{|l|}{ ICT activity to meet diverse learners needs } \\
\hline 26 & Recording lectures & 3.6 & 4 & 3.4 & 0.000 & 1.00 \\
\hline 27 & $\begin{array}{l}\text { Changing settings (e.g. colors, contrast, } \\
\text { font size, icons, menus) }\end{array}$ & 91.3 & 88 & 93.2 & 0.524 & 0.50 \\
\hline 28 & Changing settings of mouse or keyboard & 59.4 & 52 & 63.6 & 1.340 & 0.25 \\
\hline 29 & Using word prediction software & 20.3 & 20 & 20.5 & 0.000 & 1.00 \\
\hline 30 & $\begin{array}{l}\text { Using text-to-speech or screen reader } \\
\text { software }\end{array}$ & 10.1 & 14 & 8 & 0.701 & 0.40 \\
\hline 31 & Using zoom software & 18.8 & 28 & 13.6 & 3.414 & 0.07 \\
\hline 32 & Using voice recognition software & 5.1 & 12 & 1.1 & 5.721 & $0.02^{*}$ \\
\hline 33 & $\begin{array}{l}\text { Using optical character recognition } \\
\text { software }\end{array}$ & 21.7 & 24 & 20.5 & 0.073 & 0.79 \\
\hline
\end{tabular}




\begin{tabular}{|c|c|c|c|c|c|c|}
\hline 34 & Using digital pens & 4.3 & 6 & 3.4 & 0.080 & 0.78 \\
\hline 35 & Using audiobooks & 8.7 & 16 & 4.5 & 3.925 & $0.05^{*}$ \\
\hline 36 & $\begin{array}{l}\text { Using mind-mapping e-tools (e.g. } \\
\text { Inspiration) }\end{array}$ & 18.8 & 14 & 21.6 & 0.756 & 0.38 \\
\hline 37 & $\begin{array}{l}\text { Using assistive hardware (e.g. Braille } \\
\text { display, adapted keyboard, joystick, etc.) }\end{array}$ & 0 & 0 & 0 & / & / \\
\hline 38 & Using augmentative communication & 2.2 & 6 & 0 & 2.945 & 0.09 \\
\hline
\end{tabular}

Examining the differences between student teachers and other students, we discovered that the study program plays an important role in the performance of some activities. Significantly more student teachers than students from other programs use e-tools for self-assessment, compose multimodal outcomes, use voice recognition software and audio books. These findings indicate that student teachers in this study explore and use ICT that enables the establishment of an inclusive learning environment. It is encouraging that they are aware of assistive technology and the role of mainstream technology in establishing a learning environment that supports diverse needs of learners.

It was discovered that students from other programs prevail in the use of some more advanced activities when compared to student teachers, i.e. using electronic books, e-learning material from other universities, participating in online courses, sharing learning information over social networks and producing shared documents with others.

The survey results are consistent with the research of $\mathrm{Ng}$ (2012), which showed that student teachers used more advanced educational technologies only if explicitly requested to do so in learning activities.

\section{Diversity of activities performed}

The diversity of activities performed was measured by computing the number of activities reported by each individual. Activities were divided into different categories following Universal Design for Learning principles (multiple means of representation, multiple means of action \& expression, multiple means of engagement) and categories of interaction occurring during online learning (learner-content, learner-teacher, learner-learner). The division of specific activities into these two categorizations can be seen in Appendix 1 (Table 4). 
Table 2. Number of performed activities - descriptive statistics of groups and testing for differences between groups.

\begin{tabular}{|c|c|c|c|c|c|c|c|c|}
\hline & Min & Max & $\mathrm{Me}_{\text {Tot }}$ & $\mathrm{Me}_{\mathrm{Ed}}$ & $\mathrm{Me}_{\text {othr }}$ & $u$ & $z$ & Sig. \\
\hline \multicolumn{9}{|l|}{ UDL categorization } \\
\hline Multiple means of representation & 2.00 & 14.00 & 7.00 & 7.00 & 8.00 & 1736.5 & -1.90 & 0.06 \\
\hline $\begin{array}{l}\text { Multiple means of action \& } \\
\text { expression }\end{array}$ & 0.00 & 10.00 & 4.00 & 4.00 & 4.00 & 2327.0 & 0.57 & 0.57 \\
\hline Multiple means of engagement & 0.00 & 4.00 & 1.00 & 1.00 & 1.00 & 2106.0 & -0.44 & 0.66 \\
\hline \multicolumn{9}{|l|}{ Interaction categorization } \\
\hline Learner - content interaction & 2.00 & 15.00 & 10.00 & 10.00 & 10.00 & 2105.0 & -0.42 & 0.67 \\
\hline Learner - teacher interaction & 0.00 & 3.00 & 2.00 & 1.00 & 2.00 & 1469.5 & -3.52 & $0.00^{* *}$ \\
\hline Learner - learner interaction & 0.00 & 6.00 & 5.00 & 4.50 & 5.00 & 1583.0 & -2.76 & $0.01^{* *}$ \\
\hline
\end{tabular}

Following the principles, guidelines and checkpoints from the Universal Design for Learning framework (specific guidelines and checkpoints can be found in http://www.udlcenter.org/aboutudl/udlguidelines), we categorized activities from the questionnaires into three different categories. The advantage of using this framework for categorization is that it does not distinguish strictly between assistive technology and mainstream technology. As such, it is consistent with the latest developments in ICT, where many mainstream technologies include accessibility settings, and many settings or technologies that were developed primarily for meeting special needs can now serve the diverse learning needs and preferences of mainstream learners. Most activities (16) in our questionnaire were categorized under multiple means of representation, followed by multiple means of action \& expression (11) and multiple means of engagement (4). No significant differences were found between groups in the number of activities performed under each category. Not all items from our questionnaires were appropriate for use in the categorization of UDL. Therefore, we also classified activities for different types of interaction. In this categorization, ICT-activities to support diverse learner needs were not included. Comparison between groups shows there are significant differences between student teachers and other students in performing activities involving learner-teacher and learner-learner interaction. Communication and collaboration technologies (social networks, applications for sharing content and producing common content) are in fact Web 2.0 technologies that should increase the incidence of community of inquiry and collaborative learning in current learning environments. The finding that future teachers use these technologies with less diversity than other populations is not encouraging. 


\section{Personal innovativeness and diversity of ICT-activities}

With the three-item-scale of personal innovativeness (by Kim et al., 2010), we measured perceived personal innovativeness among student teachers. Within the possible range from 3 to 15 , the median of the group of education students was 6.00. It reveals a relatively low self-assessment of this characteristic among student teachers. Contrary to our expectations, the construct of personal innovativeness correlates significantly only with activities categorized into multiple means of engagement (educational games, mobile applications, virtual environments and producing shared documents).

Table 3. Spearman rho measure of correlation between personal innovativeness and number of performed ICT-activities in the group of student teachers.

\begin{tabular}{lcc}
\hline & Rho & Sign. \\
\hline Personal innovativeness & 1.00 & \\
UDL categorization of activities & & \\
Multiple means of representation & 0.08 & 0.64 \\
Multiple means of action \& expression & 0.11 & 0.50 \\
Multiple means of engagement & 0.37 & $0.02^{*}$ \\
Interaction categorization of activities & & \\
Learner - content interaction & -0.02 & 0.891 \\
Learner - teacher interaction & -0.24 & 0.14 \\
Learner - learner interaction & 0.09 & 0.57 \\
All activities & 0.15 & 0.36 \\
\hline${ }^{*} p \leq 0.05$ & & \\
& &
\end{tabular}

The results show that personal innovativeness may not be a very important factor contributing to the use of ICT for learning purposes.

\section{Conclusions}

The survey was conducted to explore the idea that competency in ICT use for learning purposes develops through the process of formal and informal learning. This article reveals the possibility that ICT, if used wisely, can be beneficial for learning. In the constantly-changing environment of ICT, the role of the learner in establishing her learning environment, which today is inevitably technology-pervasive has become more active. The literature suggests that personal factors, such as innovativeness, may play an important part in this, but our survey did not find many significant correlations to support these assumptions. This means that structural factors, such as the formal curriculum, should 
compensate for individual differences. If we believe that current ICT use is indirectly connected with future ICT use through experiences, attitudes and motivation, then looking into current ICT use for learning among student teachers is important. ICT can be a beneficial tool for establishing a learning environment that meets personal learning needs and for establishing inclusive environments in classrooms. Because of the constant development of ICT, future teachers (and other students) may not have considered every form of ICT that exists, but by implementing topics on different kinds of ICT, assistive learning, Universal Design for Learning, etc., they may become more informed users.

The results of the study show a mixed picture. The most positive result is that future teachers perform more ICT-supported activities to meet diverse learner needs in comparison to their peers. We have not researched whether they perform(ed) these activities in formal or informal environments, but it could be an effect of the formal curriculum. However, differences should have occurred in more activities, because a teacher's career entails working with diverse learners, especially with the inclusive paradigm being more pervasive. More concerning are the findings that future teachers lag behind in performing activities connected to active engagement and collaboration (e.g. virtual learning, online courses), even though all students are more prone to the passive reception of online educational content than active engagement. This indicates that something should be done to motivate student teachers and other students to be more active online with regard to learning, as developed societies are evolving towards a participative paradigm.

Another field of possible intervention is to educate students about how to exploit existing e-tools for monitoring and planning their learning. If student teachers master this, then knowledge can later be transferred to their learners. Even though we concluded that it is encouraging that not many significant differences exist between different study programs in the use of ICT for learning, all who are working in teacher education should be encouraging students to adopt innovative thinking with regards to ICT for learning, making future teachers agents of change.

\section{References}

Anderson, T. (2008). Toward a theory of online learning. In T. Anderson \& F. Elloumi (Eds.), Theory and Practice of Online Learning (pp. 45-74). Athabasca University.

Agarwal, R., \& Prasad, J. (1998). A Conceptual and Operational Definition of Personal Innovativeness in the Domain of Information Technology. Information Systems Research, 9(2), 
Arkilic, I. G., Peker, S., \& Uyar, M. E. (2013). Students' Preferences of Communication Tools for Group Projects in a Computer-supported Collaborative Learning Environment: A Survey. Procedia Social and Behavioral Sciences, 83, 1121-1125. doi:10.1016/j.sbspro.2013.06.214 Bennett, S., Bishop, A., Dalgarno, B., Waycott, J., \& Kennedy, G. (2012). Implementing Web 2.0 technologies in higher education: A collective case study. Computers \& Education, 59(2), 524-534. doi:10.1016/j.compedu.2011.12.022

Calvo, R., Arbiol, A., \& Iglesias, A. (2014). Are all Chats suitable for learning purposes ? A study of the required characteristics. Procedia - Procedia Computer Science, 27, 251-260. doi:10.1016/j. procs.2014.02.028

Centre for Excellence in Universal Design. (2012). Retrieved 1. 12. 2014 from http://universaldesign. ie/

Conole, G., de Laat, M., Dillon, T., \& Darby, J. (2008). “Disruptive technologies”, "pedagogical innovation": What's new? Findings from an in-depth study of students' use and perception of technology. Computers \& Education, 50(2), 511-524. doi:10.1016/j.compedu.2007.09.009

Dabbagh, N., \& Kitsantas, A. (2012). Personal Learning Environments, social media, and selfregulated learning: A natural formula for connecting formal and informal learning. The Internet and Higher Education, 15(1), 3-8. doi:10.1016/j.iheduc.2011.06.002

Izzo, M. V. (2012). Universal Design for Learning: Enhancing Achievement of Students with Disabilities. Procedia Computer Science, 14, 343-350. doi:10.1016/j.procs.2012.10.039 Jelfs, A., \& Richardson, J. T. E. (2013). The use of digital technologies across the adult life span in distance education. British Journal of Educational Technology, 44(2), 338-351. doi:10.1111/j.14678535.2012.01308.x

Kim, C., Mirusmonov, M., \& Lee, I. (2010). An empirical examination of factors influencing the intention to use mobile payment. Computers in Human Behavior, 26, 310-322.

Lai, K.-W., Khaddage, F., \& Knezek, G. (2013). Blending student technology experiences in formal and informal learning. Journal of Computer Assisted Learning, 29(5), 414-425. doi:10.1111/jcal.12030 Laurillard, D. (2002). Rethinking university teaching: A conversational framework for the effective use of learning technologies (2nd ed.). London: Routledge.

Levy, Y. (2008). An empirical development of critical value factors (CVF) of online learning activities: An application of activity theory and cognitive value theory. Computers \& Education, $51(4)$, 1664-1675. doi:10.1016/j.compedu.2008.04.003

McLaughlin, C., \& Lee, M. (2010). Personalised and self regulated learning in the Web 2.o era: International exemplars of innovative pedagogy using social software. Australasian Journal of Educational Technology, 26(1), 28-43.

Moore, M., \& Kearsley, G. (2012). Distance Education: A System View of Online Learning (3ed).

Wadsworth: Cengage Learning.

Mills, L. a., Knezek, G., \& Khaddage, F. (2014). Information Seeking, Information Sharing, and going mobile: Three bridges to informal learning. Computers in Human Behavior, 32, 324-334. doi:10.1016/j. chb.2013.08.008 
National Center on Design for Learning. (2014). UDL Guidelines. Retrieved 10. 12. 2014 from on http://www.udlcenter.org/aboutudl/udlguidelines

Ng, W. (2012). Can we teach digital natives digital literacy? Computers \& Education, 59, 1065-1078. Rao, K., Ok, M. W., \& Bryant, B. R. (2014). A Review of Research on Universal Design Educational Models. Remedial and Special Education, 35(3), 153-166. doi:10.1177/0741932513518980 Ravanelli, F., \& Serina, I. (2014). Didactic and Pedagogical View of E-learning Activities Free University of Bozen-bolzano. Procedia - Social and Behavioral Sciences, 116, 1774-1784. doi:10.1016/j. sbspro.2014.01.471

Sedek, M., Mahmud, R., Jalil, H. A., \& Daud, S. M. (2012). Types and Levels of Ubiquitous Technology use among ICT Undergraduates. Procedia - Social and Behavioral Sciences, 64, 255-264. doi:10.1016/j.sbspro.2012.11.030

Straub, E. T. (2009). Understanding Technology Adoption: Theory and Future Directions for Informal Learning. Review of Educational Research, 79(2), 625-649. doi:10.3102/0034654308325896 Thompson, P. (2013). The digital natives as learners: Technology use patterns and approaches to learning. Computers \& Education, 65, 12-33. doi:10.1016/j.compedu.2012.12.022 Thoms, B., \& Eryilmaz, E. (2014). How media choice affects learner interactions in distance learning classes. Computers \& Education, 75, 112-126. doi:10.1016/j.compedu.2014.02.002

UNESCO. (2011). Revision of the International Standard Classification of the Education (ISCED). Retrieved 10. 12. 2014 from http://www.uis.unesco.org/Education/Documents/UNESCO_

GC_36C-19_ISCED_EN.pdf

Web Accessibility Iniciative. (2005). Introduction to Web Accessibility. Retrieved 19. 9. 2014 from http://www.w3.org/WAI/intro/accessibility.php 


\section{Appendix}

Table 4. Categorization of items into categories of $U D L(M R, M A E, M E)$ and Model of online learning (LCI, LTI, LLI).

\begin{tabular}{|c|c|c|c|c|c|c|c|}
\hline Item & & MR & MAE & ME & $\mathrm{LCl}$ & LTI & LLI \\
\hline 1 & Using e-classroom for learning & & & & & $x$ & \\
\hline 2 & Reading electronic books & $x$ & & & $x$ & & \\
\hline 3 & Searching articles in scientific databases & & & & $x$ & & \\
\hline 4 & Searching literature in electronic library catalogues & & & & $x$ & & \\
\hline 5 & Reading online encyclopedias & $x$ & & & $x$ & & \\
\hline 6 & Reading blogs, concerning my study field & $x$ & & & $x$ & & \\
\hline 7 & Participating in online courses & & & & & $x$ & \\
\hline 8 & Listening to educational podcasts & $x$ & & & $x$ & & \\
\hline 9 & Watching educational videos & $x$ & & & $x$ & & \\
\hline 10 & $\begin{array}{l}\text { Using other (foreign) universities electronic educa- } \\
\text { tional materials and videos }\end{array}$ & $x$ & & & & $x$ & \\
\hline 11 & Playing educational games & & & $x$ & $x$ & & \\
\hline 12 & $\begin{array}{l}\text { E-tools for self-assessment (e.g. quizzes, personal- } \\
\text { ity questionnaires etc.) }\end{array}$ & & $x$ & & $x$ & & \\
\hline 13 & Using educational mobile applications & & & $x$ & & & \\
\hline 14 & $\begin{array}{l}\text { Using virtual environments for learning (e.g. } \\
\text { Second life etc.) }\end{array}$ & & & $x$ & & & $x$ \\
\hline 15 & $\begin{array}{l}\text { Composing multimodal text and other outcomes } \\
\text { (combining text, audio or video) }\end{array}$ & & $x$ & & $x$ & & \\
\hline 16 & Using electronic citation tools & & $x$ & & $x$ & & \\
\hline 17 & $\begin{array}{l}\text { Using social networks for learning: following } \\
\text { shared information about my study field }\end{array}$ & & & & & & $x$ \\
\hline 18 & $\begin{array}{l}\text { Using social networks for learning: learning about } \\
\text { events, connected to my study field (e.g. seminars, } \\
\text { trainings etc.) }\end{array}$ & & & & & & $x$ \\
\hline 19 & $\begin{array}{l}\text { Using social networks for learning: sharing infor- } \\
\text { mation about my study field }\end{array}$ & & $x$ & & & & $x$ \\
\hline 20 & $\begin{array}{l}\text { Sharing my files with others (using Dropbox, } \\
\text { Google Drive etc.) for purposes of study }\end{array}$ & & & & & & $x$ \\
\hline 21 & $\begin{array}{l}\text { Producing shared documents with others (using } \\
\text { Dropbox, Google Drive etc.) for purposes of study }\end{array}$ & & & $x$ & & & $x$ \\
\hline 22 & $\begin{array}{l}\text { Using electronic dictionaries for searching Slove- } \\
\text { nian words. }\end{array}$ & $x$ & & & $x$ & & \\
\hline 23 & $\begin{array}{l}\text { Using electronic dictionaries or translation applica- } \\
\text { tions for searching words in foreign languages. }\end{array}$ & $\mathrm{x}$ & & & $x$ & & \\
\hline 24 & $\begin{array}{l}\text { Using e-tools for making and organizing notes (e.g. } \\
\text { OneNote etc.) }\end{array}$ & & $x$ & & $x$ & & \\
\hline \multirow[t]{2}{*}{25} & $\begin{array}{l}\text { Using e-tools for planning learning process (e.g. } \\
\text { Google calendar etc.) }\end{array}$ & & $x$ & & $x$ & & \\
\hline & ICT activity to meet diverse learners needs & & & & & & \\
\hline 26 & Recording lectures & $x$ & & & & & \\
\hline 27 & $\begin{array}{l}\text { Changing settings (e.g. colors, contrast, font size, } \\
\text { icons, menus) }\end{array}$ & $x$ & & & & & \\
\hline
\end{tabular}




\begin{tabular}{|c|l|c|c|c|c|c|c|}
\hline 28 & Changing settings of mouse or keyboard & & $\mathrm{X}$ & & & \\
\hline 29 & Using word prediction software & & $\mathrm{X}$ & & & & \\
\hline 30 & Using text-to-speech or screen reader software & $\mathrm{X}$ & & & & & \\
\hline 31 & Using zoom software & $\mathrm{X}$ & & & & & \\
\hline 32 & Using voice recognition software & & $\mathrm{X}$ & & & & \\
\hline 33 & Using optical character recognition software & $\mathrm{X}$ & & & & & \\
\hline 34 & Using digital pen & $\mathrm{X}$ & & & & & \\
\hline 35 & Using audio books & $\mathrm{X}$ & & & & & \\
\hline 36 & Using mind-mapping e-tools (e.g. Inspiration) & $\mathrm{X}$ & & & & & \\
\hline 37 & Using assistive hardware (e.g. Braille display, & & $\mathrm{X}$ & & & & \\
\hline 38 & Udapted keyboard, joystick etc.) & & & & & \\
\hline & Number of items & 16 & 11 & 4 & 15 & 3 & 6 \\
\hline
\end{tabular}

*MR - Multiple means of representation

MAE - Multiple means of action and expression

ME - Multiple means of engagement

$\mathrm{LCl}$ - Learner - content interaction

LTI - Learner - teacher interaction

LLI - Learner - learner interaction

\section{Biographical note}

MAJA LEBENIČNiK is psychologist and young researcher, employed at University of Primorska, Faulty of Education. She is interested in the use of learning technology with a focus on user perspective. She has been researching the use of learning technology among university students with special needs (ICT-supported informal learning, perceived accessibility barriers, influencing factors) and the use of ICT to support learning by SEN educators and institutions. Currently she is working on her $\mathrm{PhD}$ thesis in which she is researching the use and accessibility of online learning resources.

IAN PITT lectures in Usability Engineering and Interactive Media at University College, Cork, Ireland. He took his D.Phil at the University of York, UK, then worked as a research fellow at Otto-von-Guericke University, Magdeburg, Germany, before moving to Cork in 1997 . He is the leader of the Interaction Design, E-learning and Speech (IDEAS) Research Group at UCC, which is currently working on a variety of projects relating to multi-modal human-computer interaction, eLearning, accessibility, etc.. His own research interests centre around the use of speech and non-speech sound in computer interfaces, and the design of interactive systems for use by blind and visually-impaired people. 
ANDREJA IsTENič STARČıč, associate professor is employed at Faculty of Education University of Primorska and Faculty of Civil and Geodetical Engineering University of Ljubljana. She is Honorary Fellow at Macquarie University, Sydney, Australia. Her teaching and research include instructional design, educational technology, learning environments, ICT assisted learning for people with special needs, media education, contemporary learning theories, innovation and creative production of multimedia contents. Andreja's website has details of her activities and publications: http://andreja-istenic-starcic.eu/. 